УДК 37.013 .77

DOI https://doi.org/10.32782/apv/2021.3.35

\title{
Оксана РОГОЖИНА
}

аспірантка кафедри початкової, дошкільної та професійної освіти, Харківський національний педагогічний університет імені Г.С. Сковороди, вул. Валентинівська, 2, м. Харків, Украӥна, 61168

ORCID: 0000-0002-9630-8100

Бібліографічний опис статті: Рогожина, О. (2021). Сексуальна освіта школярів як наукова проблема. Acta Paedagogica Volynienses, 3, 241-247, doi: https://doi.org/10.32782/apv/2021.3.35

\section{СЕКСУАЛЬНА ОСВІТА ШКОЛЯРІВ ЯК НАУКОВА ПРОБЛЕМА}

Ще донедавна питання сексуальної освіти школярів не було настільки актуальним, як сьогодні. На ие є свої причини: по-перше, акселерація, щзо прискорила статеве дозрівання; по-друге, великий потік різноманітної позитивної і негативної інформації; по-третє, природна дитяча допитливість.

Вже протягом тривалого часу залишається насущною проблемою необізнаність батьків, вчителів, викладачів у питаннях, пов'язаних із сексуальною освітою підростаючого покоління. Більшість молодих людей, спираючись на інформацію про особливості статевого життя, яку отримують від однолітків або з різних матеріалів, орієнтованих на дорослих, можуть наробити багато помилок у своєму юному вічі, які негативно відбиватимуться не тільки на стані їхнього здоров'я, але й на подальшому житті та благополуччі. Серед основних проблем, які вказують на дефіциит знань із питання, є зниження віку початку неповнолітніми статевого життя, щзо супроводжується збільшенням кількості штучного переривання вагітності, можливістю інфікування інфекціями, які передаються статевим шляхом та появою серед молодих дівчат матерів-одиначок.

Аналіз зарубіжної та вітчизняної психолого-педагогічної літератури засвідчує наявність різних підходів до проблеми сексуальної освіти школярів, щзо пов'язано насамперед з низьким рівнем обізнаності дорослих з иих питань. Досліджено, щзо сексуальну освіту науковиі трактують у вузькому та широкому його розумінні. Так, у більш вузькому значенні сексуальна освіта акцентує на фізіологічних і біологічних особливостях статей, проблемах статевого життя, в тому числі запобіганню випадковій вагітності $і$ досягненню безпечного статевого задоволення. Однак більшість вживають поняття «сексуальна освіта» у широкому його трактуванні ше і формування культури почуттів, гуманного ставлення до протилежної статі, підготовку до шлюбу і сімейного життя, відповідальність.

Проаналізувавщи сучасний стан дослідження проблеми сексуальної освіти школярів у вітчизняній та зарубіжній педагогічній думиі, було встановлено, щчо дослідники заклали методологічне підтрунтя та розкрили загальнотеоретичні питання статей, статевого виховання, сексуальної освіти, частково висвітлили проблеми професійної готовності вчителів до здійснення сексуальної освіти учнів.

У статті здійснено огляд наукової літератури та проаналізовано теоретичні основи сексуальної освіти школярів в прачях вітчизняних та зарубіжних науковців. Розкрито сутність поняття «сексуальна освіта» та різні підходи до його трактування.

Ключові слова: «сексуальна освіта», «статеве виховання», «статева освіта».

\section{Oksana ROGOZHINA}

Postgraduate Student at the Department of Primary, Preschool and Vocational Education, H. S. Skovoroda Kharkiv National Pedagogical University, Valentynivska str., 2, Kharkiv, Ukraine, 61168

ORCID: 0000-0002-9630-8100

To cite this article: Rogozhina, O. (2021). Seksualna osvita shkoliariv yak naukova problema [Sexual education of schoolchildren as a scientific problem]. Acta Paedagogica Volynienses, 3, 241-247, doi: https://doi.org/10.32782/apv/2021.3.35

\section{SEXUAL EDUCATION OF SCHOOLCHILDREN AS A SCIENTIFIC PROBLEM}

Until recently, the issue of school sex education was not as relevant as it is today. There are reasons for this: first, the acceleration that accelerated puberty; secondly, a large flow of various positive and negative information; third, the natural childish curiosity.

For a long time now, the ignorance of parents, teachers and educators on issues related to the sexual education of the younger generation has been a pressing problem. Most young people can make many mistakes at a young age based on information about their sexual life from peers or from various adult-oriented materials, which will negatively affect not only their health but also their future. life and well-being. Among the main problems that indicate a lack of knowledge on 
this issue are the decrease in the age of onset of sexual intercourse by minors, accompanied by an increase in abortion, the possibility of sexually transmitted infections and the emergence of single girls among single mothers.

The analysis of foreign and domestic psychological and pedagogical literature shows the existence of different approaches to the problem of sexual education of schoolchildren, which is primarily due to the low level of awareness of adults on these issues. It has been studied that sex education is interpreted by scientists in its narrow and broad sense. Thus, in a narrower sense, sex education focuses on the physiological and biological characteristics of the sexes, the problems of sexual life, including the prevention of accidental pregnancy and achieving safe sexual pleasure. However, most use the concept of "sex education" in its broad interpretation and the formation of a culture of feelings, humane treatment of the opposite sex, preparation for marriage and family life, responsibility.

Analyzing the current state of research on the problem of sexual education of schoolchildren in domestic and foreign pedagogical thought, it was found that the researchers laid the methodological basis and revealed general theoretical issues of sex, sex education, sex education, partially highlighted the problems of professional readiness of teachers for sex education.

The article reviews the scientific literature and analyzes the theoretical foundations of sexual education of schoolchildren in the works of domestic and foreign scientists. The essence of the concept of "sex education" and different approaches to its interpretation are revealed.

Key words: «sex education», «sex education», «sex education».

Вступ. Сучасний світ переживає докорінну зміну підходів в освіті, це зумовлено переорієнтацією освітньої системи на розвиток

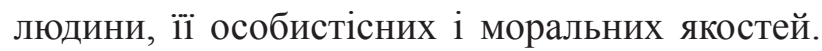
Державні документи 3 питань національної освітньої політики передбачають знання і розуміння учнями загальнолюдських та національних цінностей, цінностей сімейного життя, самостійності у прийнятті рішень, збереження репродуктивного, фізичного, психічного, соціального та духовного здоров'я нації.

Зміни, які відбуваються в Україні стосуються не тільки економічних та політичних питань, а й освітніх, суттєвою складовою частиною яких є проблема виховання різнобічно розвиненої особистості, гідного громадянина України, представника тієї чи іншої професії та статі. В сучасній школі патріотичному та громадянському вихованню приділяється значна увага, трохи менше працюють над професійною орієнтацією учня. Проте наразі існує проблема освіти школярів як представників певної статі, що здатні будувати здорові статеві стосунки.

Основна частина. У педагогічних науці сексуальну освіту досліджують у різних напрямax i аспектах. 3 огляду на це особливий інтерес становить спадщина видатних вчених минулого століття П. Блонського, Г. Ващенка, Л. Виготського, А. Макаренка, В. Сухомлинського, які у своїх працях приділяли значну увагу проблемі статевого виховання, сексуальної просвіти, культури міжстатевих стосунків, підготовки молоді до сімейного життя.

Проблема сексуальної освіти $\epsilon$ цікавою i для сучасних досліджень вітчизняних педагогів та знайшла своє відбиття в дисертаційних та монографічних працях. Ними вивчались такі аспекти проблематики: теоретичні основи сексуальної освіти (I. Петрище, В. Кравець, Л. Слинько); статеве виховання в сім'і (Т. Говорун, Г. Дейнега, О. Шарган); особливості статевого виховання та розвитку підлітків, старшокласників (О. Сечейко, С. Суматохіна, Г. Дьоміна); статевої та сексуальної просвіти (I. Мезеря, О. Петрунько); гігієнічні питання сексуальної освіти (І. Юнда); підготовка до виконання батьківських та материнських функцій (В. Бойко, Д. Луцик, Г. Чередниченко); підготовка вчителя до сексуальної освіти школярів (В. Бойко, О. Главацька, О. Рибалко).

Усі ці дослідження, прямо чи опосередковано допомагають закладам освіти у розв'язанні покладених на них завдань, озброюють учителя сучасними технологіями та підходами, хоча інші соціальні чинники впливу на дитину, як правило, цілеспрямованого вдосконалення не зазнають. Слід також зауважити, що науковий доробок з цієї проблеми в українській порівняльній педагогіці є досить незначний.

Щодо сексуальної освіти школярів, то більшість теоретиків підкреслюють, що вона $\epsilon$ одночасно процесом, як виховання, так і навчання, водночас прийнято розглядати сексуальну освіту (просвіту) (англ. Sex education) або статеве виховання як процес надання знань про анатомію статевих органів людини, статеве розмноження (зачаття, запліднення, розвиток зародка і плоду, пологи), секс та статевий акт, репродуктивне здоров'я, емоційні стосунки 3 сексуальним партнером/партнеркою, репродуктивні права і відповідальності, планування сім’ї, контрацепцію, контроль над 
народжуваністю та інші аспекти сексуальної поведінки людини. В цьому визначенні поняття сексуальна освіта та статеве виховання розглядаються синонімічно, водночас маємо уточнити, що сексуальна освіта містить відомості про сексуальність, включно з інформацією про планування сім’̈, про всі аспекти сексуальності індивіда, зокрема й про зовнішній вигляд оголеного тіла, сексуальну орієнтацію, про статеве задоволення, цінності, прийняття рішення щодо статевого зв'язку, спілкування, інфекції, що передаються статевим шляхом, і як уникнути їх.

У сучасній педагогічній літературі пропонується таке визначення статевого виховання та статевої освіти: «Статеве виховання - складова частина виховного процесу, що забезпечує правильний статевий розвиток дітей і молоді та оволодіння нормами взаємин 3 представниками протилежної статі, а також правильне ставлення до питань статі. Статеве виховання нерозривно пов'язане 3 фізичним, розумовим, моральним та естетичним розвитком особистості. Починається в дошкільному віці й зумовлюється переважно соціально-психологічними факторами. Засвоюючи в родині, дошкільному закладі освіти загальні моральні норми, хлопчики й дівчатка в той же час опановують правила, що передбачають деяку відмінність у їхній поведінці залежно від статі. Згодом, з початком статевого дозрівання, до факторів соціальнопсихологічних додається фізіологічний. У підлітковому та юнацькому віці, коли завершується статеве дозрівання, більшого значення набуває статева освіта» (Гончаренко, 1997).

Зустрічаємо й такі визначення поняття: це формування свідомості дитини відповідно до іiі належності до певної статі, забезпечення умов для нормального психосексуального розвитку особистості, засвоєння суспільно усталених нормативів статевої поведінки, яке здійснюється завдяки характеру спілкування дитини у колі сім’ї та навчання орієнтованих на успішне виконання статевих ролей.

Розглядаючи поняття «сексуальна освіта» значно ширше, це інформування школярів про функціонування статевих органів, формування цінностей і етичної відповідальності як сексуальної істоти; знання про тіло людини і його репродуктивних органів; психологічна і соціальна оцінка чоловіки і жінки, які мають бути коханими, любити і поважати партнера. У центрі уваги сексуальної освіти лежить психофізичний розвиток, особисті відносини, здоров'я, культура і духовність, проявляється по-різному у різних людей і етапах життя; оцінка зв'язку i любові, як центральних компонентів сексуальності; визнання і оцінка відповідальності і права на недоторканність приватного життя, як невід'ємні елементи сексуальної поведінки; повага до різноманіття у сексуальності; визнання і оцінка прав дітей, підлітків і молодих людей; підготовка до шлюбу і сімейного життя, формування культури почуттів, відповідальність за сім’ю.

За визначенням ЮНЕСКО, сексуальна освіта- відповідний вікові та культурі підхід до викладання тем, пов'язаних зі статевим розвитком i сексуальними стосунками, який забезпечує передавання наукової, реальної та об'єктивної інформації і дає змогу осмислити власні ціннісні орієнтири й погляди, а також набути навичок ухвалення рішень, ведення діалогу та зниження ризиків, пов'язаних із багатьма аспектами сексуального життя.

Отже, квінтесенція поняття «сексуальна освіта» становить процес і результат удосконалення здібностей i поведінки особистості, за якого вона досягає соціальної зрілості, індивідуального зростання, сформованості рівня культури в суспільстві.

Всесвітня організація охорони здоров'я (BOO3) дотримується позиції, що сексуальна освіта в школах є надзвичайно важливою для благополуччя молоді та їх сексуального здоров’ я.

\section{Результати та їх обговорення.}

Мета статті полягає в аналізі теоретичних основ здійснення сексуальної освіти школярів та визначення ролі вчителя та закладу освіти у цьому процесі.

Аналіз наукової літератури дає можливість стверджувати, що поняття «сексуальна освіта» часто ототожнюють 3 поняттям «статеве виховання».

Цінний внесок в розробку проблем статевого розвитку і сексуальної освіти дітей та підлітків вніс П. Блонський. Сексуальна освіта, на думку вченого, має починатися змалку. Перша й основна вимога до неї в цей період - здорове середовище. Другою вимогою є нагляд за дитиною і тими, хто спілкується з нею. Найкращими засобами сексуальної освіти за словами 
П. Блонського є творча і здорова праця, юнацький ідеалізм і ділова повага до людини.

Спираючись на всебічний аналіз численних фактів П. Блонський надає важливого значення сексуальній просвіті, яка «повинна бути підпорядкована педагогічним завданням: вона повинна не просто інформувати, а саме виховувати. ĨÏ не можна обмежувати чисто гігієнічним змістом, звертаючись лише до почуття обережності. Звісно, це важлива частина статевої просвіти, але тільки частина... .Людське сексуальне життя має багатший зміст» (Блонський, 2007).

Сексуальна освіта школярів, за словами Г. Ващенка, має грунтуватися на їх моральному вихованні: «...українську молодь треба виховувати в дусі статевої чистоти і стриманості... кожний українець мусить бути моральним у дусі української традиційної моралі, заснованій на засадах християнства. Це потрібне і для особи, і для суспільства.... Важливо зосередити увагу дітей на формуванні моральних «гальм», які б запобігали відхиленням від норми у статевій поведінці, а також на морально-психологічних питаннях, розв'язання яких сприяло б формуванню правильних взаємин між статями, унеможливлювало статеву розпусту. Передусім необхідно виховувати в учнів повагу до себе, чоловічу та жіночу гідність» (Ващенко, 1997).

Особливий інтерес викликають погляди Л. Виготського щодо сексуальної освіти школярі в основі якої виступає статеве просвітництво, як ознайомлення дітей з самого раннього віку 3 науковим поглядом на статеве життя (Федяєва, 2007).

Питанням сексуальної освіти значну увагу приділяв А. Макаренко. Він вважав, що правильна сексуальна освіта - це формування культури особистості, виховання iï як майбутнього сім'янина, виховання глибокої поваги до жінки. Мета сексуальної освіти, на думку А. Макаренка, - виховати дітей так, аби вони ставились до кохання як до серйозного і глибокого почуття, щоб свою насолоду, своє кохання і щастя реалізували в сім'ї.

А. Макаренко стверджував, що питання сексуальної освіти стають важкими тоді, коли їх розглядають окремо і коли їм надають занадто великого значення. Пропонував проведення в школі бесід (з хлопцями і дівчатами окремо) 3 питань статевої гігієни, а із старшокласниками - $з$ проблем небезпеки венеричних захво- рювань. Але такі бесіди мають здійснюватися через формування статевої моралі. Приводом для таких бесід можуть бути: цинічні розмови, підвищений інтерес до чужих сімейних справ, підозріле і не зовсім пристойне ставлення до любовних пар, легковажна дружба 3 дівчатами, неповага до жінки, надмірне захоплення нарядами, раннє кокетство, інтерес до книг, які надто відверто зображують статеві стосунки.

В. Сухомлинський розкриваючи педагогічну мудрість статевого виховання говорить про виняткову важливість гармонії фізичного розвитку і духовного життя. Педагог неодноразово наполягав, що багато того, що важливо у сфері статевого виховання, менше всього слід зв'язувати з порадами, що стосуються безпосередньо цієї сфери. Педагогічна мудрість статевого виховання полягає в тому, щоб якнайменше говорити про фізіологічне у взаємовідносинах статей (Сухомлинський, 1970).

Теоретико-практичні аспекти проблеми сексуальної освіти дітей та підлітків 3 позиції психології та педагогіки досліджували: Д. Ісаєв, В. Каган, І. Кон, Л. Верб та ін. У роботах науковців розглядаються питання адекватного ставлення до представників протилежної статі, 3'ясовуються основні психофізіологічні відмінності представників різної статі та віку, висуваються пропозиції щодо методичного забезпечення виховного впливу.

На думку М. Козакевича, статева освіта і виховання, котрі охоплюють, головним чином, інформаційну діяльність, повинні починатись якомога раніше і бути цілеспрямованим процесом, що циклічно поглиблюється, 3 кожним циклом в кілька років, з глибшим рівнем знань і об'ємом інформації, враховуючи вік і стадії розвитку дітей і молоді.

Так, психолог Л. Верб під сексуальною освітою розуміє систему медико-педагогічних заходів по навчанню та вихованню батьків, дітей, підлітків правильного розуміння питань статі, що сприяє гармонійному розвитку підростаючих поколінь, накопиченню сексологічних знань, повноцінному формуванню дітородної функції, почуття відповідальності за здоров'я і благополуччя майбутнього чоловіка (жінки), дітей, тобто зміцнення шлюбу і сім'ї.

I. Петрище визначає сексуальну освіту школярів як комплекс систематичних впливів на людину з метою вироблення у неї позитивних моральних якостей, рис характеру, особистісних 
установок з питань статі, які вимагають вирішення багатьох завдань починаючи 3 усвідомлення дитиною своєї статевої приналежності і закінчуючи питаннями статевої моралі дорослого. Саме I. Петрище наголошує на тому, що статеве виховання має базуватися на статевій освіті, тобто навчанні і вихованні з метою засвоєння школярами відповідних знань, в результаті чого вони зможуть досягти певного рівня освіченості (Петрище, 1990).

Аналізуючи праці Е. Ільїна, можна виділити такі завдання сексуальної освіти:

1. Надати молодій людині необхідні знання $з$ фізіології та анатомії людини, психології та гігієни статевого життя.

2. Формувати свідоме ставлення до статевих відносин, соціальну відповідальність за статеву поведінку; правильні уявлення про статевих акт, запліднення, внутрішньоутробний розвиток та пологи.

3. Здійснювати профілактику ранніх статевих контактів та формування навичок безпечної статевої поведінки.

4. Коригувати ризиковану та суспільно небезпечну сексуальну поведінку.

5. Виховувати якості, що сприяють формуванню психологічної маскулінності та фемінності, прагнення мати міцну та здорову сім’ю.

Так, статеве виховання, як визначає В. Кравець, - це організований і цілеспрямований процес формування фізичних, психічних i моральних якостей особистості, установок, що визначають корисне для суспільства ставлення людини до протилежної статі та високоморальні стосунки між статями.

В.Кравець наголошує: «сутність статевого виховання не в тому, щоб іти за статевим розвитком школяра, йти позаду нього, а щоб випереджати процес статевого дозрівання, формувати той морально-психологічний і емоційно-естетичний базис, без якого статеві переживання і стосунки ускладнюють життя людини».

Т. Говорун зазначає, що стратегія сексуальної освіти має бути орієнтована на розвиток сексуальності як складової частини свідомості та самосвідомості, має інтегрувати чуттєвість в психологію дитини, сприйняття себе сексуальною, люблячою істотою. Сексуальність за такої умови виступає органічною часткою повсякденної життєдіяльності дитини, пронизує сприйняття нею себе та оточуючих людей.
Сексуальна освіта дітей та юнацтва за словами О. Кікінежді $є$ ефективною за умови дотримання певних принципів іiі реалізації. Серед них - об'єктивність, науковість пояснень, доступність віковим можливостям розуміння та адекватність досвіду дитини, позитив у ставленні до проявів сексуальності, природність поведінки дорослих та авторитетність джерел інформації.

Вітчизняні науковці О. Василенко, О. Главацька поняття «статеве виховання» трактують як цілеспрямований процес виховання культури статевих відносин, тісно пов'язаної з формуванням загальної культури. Одночасно це і здобуття інформації з питань медико-біологічного характеру, систематизованої й адаптованої відповідно до віку системи юридичних знань 3 питань шлюбно-сімейних відносин, гігієни дівчини і хлопця, формування відповідального ставлення за свої дії та вчинки, відповідального батьківства (Василенко, 2006).

Вагомим підгрунтям виховання у підлітків культури міжстатевих стосунків на думку О. Рибалко є зміст, форми та методи сексуальної освіти в школі, що проєктуються і впроваджуються вчителем відповідно до актуальних проблем становлення особистості підлітків. Культура міжстатевих стосунків - це інтегративне, внутрішньо-особистісне утворення, яке виступає регулятором поведінки підлітка в міжстатевих стосунках і характеризується сформованістю в нього позиції довіри, поваги, дружелюбності й гуманного ставлення до протилежної статі (Рибалка, 2005).

О. Кузнецова розглядає статеве виховання як особливу складову частину морального виховання. Статеве виховання має психологічний, соціальний, медичний і філософський аспекти. Його характерний предмет - виховання ставлення особистості однієї статі до протилежної статі та пов'язаних із цим найтонших і найскладніших навичок самоконтролю і поведінки (Кузнецова, 2004).

О. Бялик статеве виховання визначає як складову частину загального виховного процесу, що забезпечує правильний статевий розвиток дітей і молоді й сприяє оволодінню ними нормами взаємин із представниками протилежної статі зокрема, $\epsilon$ визначальним чинником формування особистості, за допомогою якого реалізується 
соціальна, комунікативна і виховна функції (Бялик, 2017).

У зарубіжних наукових публікаціях виокремлюємо такі визначення: «сексуальна освіта має бути невід'ємною частиною навчального процесу, починаючи 3 дитинства і продовжуючи життя дорослого та його процес навчання протягом усього життя. Вона має бути для всіх дітей, молоді та дорослих, включаючи тих, хто має фізичне навчання або емоційні труднощі. Це повинно формувати духовні та моральні цінності, розвивати навички спілкування та прийняття рішень. Це повинно виховувати самооцінку, самосвідомість, почуття моральної відповідальності та навички уникати раннього сексуального досвіду та протистояти йому»; «сексуальне виховання можна визначити як будь-яку комбінацію навчального досвіду сприяння добровільній поведінці, що сприяє сексуальному здоров'ю. Сексуальна освіта у підлітковому віці має бути зосереджена на забезпеченні повного змісту проти всебічної інструкції вчителями, батьками, медичними працівниками, а також на контексті (у школі та за їі межами) такого навчання».

Висновки. У зв'язку з цим, стає зрозумілим, що проблема сексуальної освіти школярів потребує подальшого дослідження, а саме теоретико-методичні засади та педагогічні умови для розвитку готовності вчителів до здійснення такої діяльності.

Перспективи подальших досліджень полягають у вивченні сучасних моделей сексуальної освіти школярів.

\section{ЛІТЕРАТУРА:}

1. Бялик О.В. Сучасні тенденції статевого виховання учнівської молоді в країнах Євросоюзу : дис. ... д-ра пед. наук : 13.00.07. Умань, 2017. $547 \mathrm{c}$.

2. Василенко О. В. Педагогічні умови статевого виховання старших підлітків у позаурочній діяльності : дис. ... канд. пед. наук : 13.00.07. Київ, 2006. 168 с.

3. Ващенко Г. Вибрані педагогічні твори. Дрогобич : Видавнича фірма «Відродження», 1997. 214 с.

4. Главацька О. Проблема підготовки майбутніх вчителів до статевого виховання учнів : дис. ... канд. пед. наук : 13.00.04. Тернопіль, 2000. 178 с.

5. Гончаренко С. Український педагогічний словник. Київ : «Либідь», 1997. 366 с.

6. Кравець В. П. Історія гендерної педагогіки: навч. посіб. для студ. вищих навч. закладів. Тернопіль : Джура, 2005. $439 \mathrm{c}$.

7. Кузнецова О. А. Статеве виховання школярів: навч. посіб. для студ. вищ. навч. закл. Миколаїв : ІЛІОН, 2004. $176 \mathrm{c}$.

8. Мезеря I. В. Актуальні проблеми статевого виховання у школі на сучасному етапі: посіб. для самостійної роботи слухачів курсів підвищення кваліфікації. Луганськ : «Знання», 2003. 64 с.

9. Петрище И.П. О половом воспитании детей и подростков. Минск : Народная асвета, 1990. 160 с.

10. Рибалка О. Я. Формування готовності студентів біологічних факультетів до виховання у підлітків культури міжстатевих стосунків : дис. ... канд. пед. наук: 13.00.04. Кіровоград, 2005. 236 с.

11. Сухомлинський В. О. Хлопчики і дівчата - чоловіки і жінки. Народження громадянина. Київ : Рад. школа, 1970. $372 \mathrm{c}$.

12. Федяєва В.Л., Кравченко Т.В. Статеве виховання школярів: сторінками історії (20-30-ті роки ХХ століття): Хрестоматія. Херсон : Видавництво ХДУ, 2007. 184 с.

13. WHO Regional Strategyon Sexual and Reproductive Health // Reproductive Health / Pregnancy Programme Copenhagen, Denmar. - Copenhagen, 2001. - (November). - 41 s. [Електронний ресурс]. - Режим доступу : www.euro.who.int/document/e74558.pdf

14. United Nations Educational, Scientific and Cultural Organisation. International Guidelines on Sexuality Education: An evidence informed approach to effective sex, relationships and HIV/STI education. Een rapport van United Nations Educational, Scientific and Cultural Organization, 2009 [Електронний ресурс]. - Режим доступу : http://unesdoc.unesco.org/images/0018/001832/183281e.pdf.

\section{REFERENCES:}

1. Byalyk O.V. (2017) Suchasni tendentsiyi statevoho vykhovannya uchnivs'koyi molodi v krayinakh Yevrosoyuzu [Current trends in sexual education of student youth in the European Union]. Uman', 547 p. (in Ukrainian)

2. Vasylenko O. V. (2006) Pedahohichni umovy statevoho vykhovannya starshykh pidlitkiv u pozaurochniy diyal'nosti [Pedagogical conditions of sexual education of senior teenagers in extracurricular activities]. Kyyiv, 168 p. (in Ukrainian) 
3. Vashchenko H. (1997) Vybrani pedahohichni tvory [Selected pedagogical works]. Drohobych: Vydavnycha firma «Vidrodzhennya», 214 p. (in Ukrainian)

4. Hlavats'ka O. (2000) Problema pidhotovky maybutnikh vchyteliv do statevoho vykhovannya uchniv [The problem of preparing future teachers for sexual education of students].Ternopil', 178 p. (in Ukrainian)

5. Honcharenko S. (1997) Ukrayins'kyy pedahohichnyy slovnyk [Ukrainian pedagogical dictionary]. Kyyiv: «Lybid'», 366 p. (in Ukrainian)

6. Kravets' V. P. (2005) Istoriya hendernoyi pedahohiky [History of gender pedagogy].Ternopil': Dzhura, 439 p. (in Ukrainian)

7. Kuznetsova O. A. (2004) Stateve vykhovannya shkolyariv [Sex education of schoolchildren]. Mykolayiv: ILION, 176 p. (in Ukrainian)

8. Mezerya I. V. (2003) Aktual'ni problemy statevoho vykhovannya u shkoli na suchasnomu etapi [Actual problems of sex education at school at the present stage]. Luhans'k: «Znannya», 64 p. (in Ukrainian)

9. Petryshche Y.P. (1990) O polovom vospytanyy detey y podrostkov [About sex education for children and adolescents]. Mynsk: Narodnaya asveta, 160 p.(in Belarus)

10. Rybalka O. YA. (2005) Formuvannya hotovnosti studentiv biolohichnykh fakul'tetiv do vykhovannya u pidlitkiv kul'tury mizhstatevykh stosunkiv [Formation of readiness of students of biological faculties for education at teenagers of culture of intergender relations]. Kirovohrad, 236 p. (in Ukrainian)

11. Sukhomlyns'kyy V. O. (1970) Khlopchyky i divchata - choloviky i zhinky. Narodzhennya hromadyanyna [Boys and girls - men and women. Birth of a citizen]. Kyyiv: Rad. shkola, 372 p. (in Ukrainian)

12. Fedyayeva V.L. (2007) Stateve vykhovannya shkolyariv: storinkamy istoriyi (20-30-ti roky KHKH stolittya) [Sex education of schoolchildren: pages of history (20-30s of the XX century)]. Kherson: Vydavnytstvo KHDU, 184 p. (in Ukrainian)

13. WHO Regional Strategyon Sexual and Reproductive Health // Reproductive Health / Pregnancy Programme Copenhagen, Denmar. - Copenhagen, 2001. - (November). - 41 s. [Електронний ресурс]. - Режим доступу : www.euro.who.int/document/e74558.pdf

14. United Nations Educational, Scientific and Cultural Organisation. International Guidelines on Sexuality Education: An evidence informed approach to effective sex, relationships and HIV/STI education. Een rapport van United Nations Educational, Scientific and Cultural Organization, 2009 [Електронний ресурс]. - Режим доступу : http://unesdoc.unesco.org/images/0018/001832/183281e.pdf. 